\title{
TRANSLINGUAGEM: UMA ABORDAGEM DOS ESTUDOS EM CONTEXTO ESTRANGEIRO E BRASILEIRO
}

\section{TRANSLANGUAGING: AN APPROACH TO STUDIES IN A FOREIGN AND BRAZILIAN CONTEXT}

\section{Cibele Krause-Lemke*}

\section{RESUMO}

Este artigo tem como objetivo principal discutir o conceito de translinguagem por meio da análise de artigos acadêmicos publicados acerca desta temática em contexto estrangeiro e brasileiro. A problemática investigada levou em conta discursos e práticas que vinculam o Brasil a uma realidade monolíngue, as quais induzem um apagamento das realidades multilíngues existentes em território brasileiro. Neste sentido, embora o Brasil seja constituído por diversas etnias, idiomas e culturas, estas marcas que o identificam como país parecem estar apagadas nas políticas educacionais brasileiras. Em vista disso, os principais objetivos foram: buscar fontes bibliográficas acerca do conceito de translinguagem e definir sua abrangência e foco em artigos publicados em contexto estrangeiro e brasileiro. $\mathrm{O}$ método que conduziu a pesquisa está embasado em um modelo qualitativo conforme Denzin \& Lincoln (2006). Tendo em vista as pesquisas analisadas, o ensino pautado em uma pedagogia translíngue contribuiria para uma aprendizagem mais inclusiva e com mais possibilidades de acesso ao conhecimento. O conceito de translinguagem vincula-se a uma pedagogia prática de linguagem, a qual busca desenvolver estratégias de ensino e de formação docente em cenários multilíngues.

Palavras-chave: translinguagem; multilinguismo; práticas linguísticas.

\section{ABSTRACT}

The main aim of this paper is to discuss the concept of translanguaging through the analysis of academic articles published on this topic in foreign and Brazilian context. The research question took into account discourses and practices that link Brazil to a monolingual reality, which induce a deletion of the multilingual realities existing in the Brazilian territory. Therefore, although Brazil is constituted of different ethnicities, languages and cultures, these traces that identify it as a country seem to have been erased from the Brazilian educational policies. In view of this, the main objectives were to search bibliographic sources about the concept of translanguaging and to define its scope and focus on articles published in a foreign and Brazilian context. The method that led the research is based on a qualitative model according to Denzin \& Lincoln (2006). In view of the publications

\footnotetext{
* Universidade Estadual do Centro-Oeste do Paraná, UNICENTRO, Campus de Irati, PR, Brasil. cklemke@unicentro.br

Orcid: https://orcid.org/0000-0001-9776-4135
} 
that were analyzed, teaching based on translanguaging pedagogy would contribute to a more inclusive learning and would enable more access to knowledge. The concept of translanguaging is linked to a practical language pedagogy, which seeks to develop teaching and teacher training strategies in multilingual settings.

Keywords: translanguaging; multilingualism; linguistic practices.

\section{INTRODUÇÃO'}

Este artigo tem como objetivo principal discutir o conceito de translinguagem por meio da análise de artigos acadêmicos publicados acerca desta temática em contexto estrangeiro e brasileiro. Surge em decorrência de outros estudos realizados em contexto brasileiro, nos quais discutimos práticas multilíngues na escola. Portanto, a problemática tratada origina-se em discursos e práticas que vinculam o Brasil a uma realidade monolíngue e, com isso, se trabalhe sistematicamente para o apagamento do multilinguismo existente em território brasileiro. Várias foram as políticas implantadas para se inserir não só no imaginário brasileiro, mas também nas práticas cotidianas de linguagem, a noção de que o país é monolíngue, resquícios, portanto, das políticas de branqueamento e repressão linguística que imperaram no Brasil durante o governo de Getúlio Vargas (1930-1945). No entanto, várias línguas sempre foram faladas em território nacional e, apesar de algumas terem sido extintas, outras permanecem (KRAUSE-LEMKE, 2010).

Ao levar em conta esta realidade, ou seja, a caracterização monolíngue das políticas linguísticas, sobretudo as que são direcionadas às diretrizes de ensino, em cenário brasileiro, desde a minha pesquisa de doutorado, tenho analisado contextos, no sul do Brasil, que são predominantemente bi/multilíngues, nos quais há o uso de mais de uma língua nas práticas cotidianas, em especial, nos usos das línguas na escola - nas práticas de ensino e aprendizagem.

A pesquisa inicial a qual me refiro (KRAUSE-LEMKE, 2010) teve como foco uma região do centro-sul do estado do Paraná - na qual predominam pelo menos duas línguas veiculares: o português e o ucraniano, sendo esta, o ucraniano, a língua de imigração da comunidade ou de herança ${ }^{2}$. Assim, o estudo foi desenvolvido em

1. Este trabalho é resultado da pesquisa de Pós-Doutorado desenvolvida na Universidade de Southampton, durante o ano de 2019. Projeto financiado pelo $\mathrm{CNPq}$, processo número: 203032/2018-7.

2. Segundo Fonseca, Weiss e Dutra (2018, p.1275), apoiadas em Commins (1983), "o conceito de língua de herança remete à língua que o sujeito recebe de sua família - justamente como uma herança. $\mathrm{O}$ contato estabelecido com a língua considerada de herança costuma dar-se de forma natural, na interação com o membro da família falante da língua e geralmente na primeira infância do indivíduo". 
contexto de imigração português-ucraniano, sendo que, no ambiente escolar, além das duas línguas, na escola, os alunos contavam com o ensino/aprendizagem do inglês e do espanhol no currículo escolar, no horário normal da escola e, também, da língua ucraniana em período contraturno. Os resultados do estudo apontaram para o fato de que, embora as produções e publicações evidenciassem um movimento em direção ao estudo das realidades multilíngues, a política linguística que atravessava tais textos ainda se pautava em ideais monolíngues. Em relação às práticas linguísticas escolares, observou-se que os alunos manifestavam um saber elaborado das línguas, ao alternarem entre o português, o ucraniano e o espanhol, e ao negociarem seus conhecimentos linguísticos com as docentes. No entanto, não reconheciam as suas práticas como plurilíngues, fato que está diretamente atrelado ao não reconhecimento da legitimidade de usos da língua de imigração e da língua estrangeira em contexto escolar.

Posteriormente, demos continuidade à pesquisa por meio de um projeto ${ }^{3}$ que teve como foco o estudo das línguas de imigração e de línguas de fronteira em contextos formais de ensino e aprendizagem, tendo como objetivo central a análise de práticas linguísticas escolares em dois diferentes contextos: línguas de imigração - no centro-sul do estado do Paraná e as línguas de fronteira - na região de Foz do Iguaçu, na qual se ressalta o uso do espanhol e do português no âmbito do Programa de Escolas Interculturais de Fronteira (PEIF). Esse programa do Ministério da Educação (MEC) foi desenvolvido em parceria com as prefeituras das cidades de região de fronteira, o qual funcionava por meio de intercâmbio docente. A pesquisa em destaque foi realizada nas cidades de Foz do Iguaçu (Brasil) e Puerto Iguazú (Argentina), onde, uma vez por semana, professores argentinos ministram aulas no contexto brasileiro e professores brasileiros ministram aulas no contexto argentino.

Com base nesse estudo, foi possível concluir que, em relação ao entorno de fronteira Brasil-Argentina, nos discursos e nas práticas, as línguas têm papel e posições diferentes nos contextos estudados. Em relação ao uso do português nas aulas ministradas no âmbito do PEIF, essa se apresentou como uma língua dominante, já que havia certa resistência dos alunos brasileiros em realizar as atividades de ensino/aprendizagem por meio da língua espanhola, o que pode ser justificado por alguns fatores, entre eles, o status das línguas. No imaginário dos alunos, a língua espanhola associa-se ao seu espaço de circulação. Como se está em uma região de fronteira, com um trânsito intenso de pessoas e mercadorias, e o espanhol, neste contexto, é híbrido, e a vinculação entre língua e cultura está muito baseada na

3. O projeto mencionado teve como título: "Política Linguística no estado do Paraná: Línguas de imigração e Línguas de Fronteira". Processo n 476204/2013 -5 - APQ (2013-2017) 
experiência do vai-e-vem da fronteira. Neste sentido, os alunos relacionavam o espanhol como não sendo uma "legítima" de ser aprendida, ou ainda, uma língua vinculada apenas ao intercâmbio comercial.

Por outro lado, houve uma postura positiva dos alunos argentinos em aprenderem o português. Por meio da análise de interações, observamos que as aulas de português, no lado argentino, encaminhavam-se para o monolinguismo em português (os professores que trabalhavam no programa eram brasileiros e as aulas ministradas em português, sem buscar correlação entre o português e o espanhol, ou até mesmo ao Portunbol). Ainda, por meio dos programas de rádio e televisão que eram veiculados naquela cidade de fronteira, os alunos tinham contato com o português, o que aumentava seu interesse pela língua. Já as aulas de espanhol no contexto brasileiro (ministradas por professores argentinos) possibilitaram mais alternâncias multilíngues, ou seja, houve mais intercâmbio entre as línguas (português e espanhol) e os docentes se utilizaram de recursos nas duas línguas para as práticas pedagógicas, embora nem sempre os alunos demonstrassem interesse em participar das aulas falando em espanhol.

No contexto de imigração - português/ucraniano/espanhol, em sala de aula, o uso da língua ucraniana acontecia por inserções parentéticas, ou seja, algumas expressões, em alguns momentos de interação. Já no contexto social e familiar, a língua ucraniana mostrou-se (e mostra-se) vital para as interações. Com isso, pudemos concluir que a língua de imigração não tem um espaço legítimo em sala de aula, mas o tem nos âmbitos extraescolares. Ainda, por meio das análises, foi possível concluir que o português apresentava-se como a língua dominante na região de imigração e na região de fronteira, sendo a principal língua usada na condução do processo de ensino. Já o espanhol caracterizava-se como língua curricular no contexto de imigração, direcionada tanto ao desenvolvimento de conteúdos léxicos, quanto ao trabalho voltado ao vestibular. Neste sentido, a dinâmica de uma pedagogia monolíngue parecia imperar nos dois contextos pesquisados, mesmo estando alunos e professores imersos em comunidades bi/multilíngues.

Essas pesquisas proporcionaram um conjunto de dados e de interpretações que nos permite asseverar que há a necessidade de uma reconceitualização do ensino de línguas, tanto ao problematizar os discursos hegemônicos acerca das línguas, como ao trabalhar para que práticas linguísticas plurilíngues sejam legitimadas, sobretudo, na escola.

É, pois, neste viés, que surge o interesse por vincular essas práticas multilinguísticas ao conceito de translinguagem, ainda em desenvolvimento em contexto brasileiro, porém já mais avançado em trabalhos publicados fora do Brasil. 
Para tanto, determinamos como objetivo investigar e construir conhecimento acerca do conceito de translinguagem por meio de estudos que se desenvolvem em cenário estrangeiro e brasileiro, buscando analisar e construir um mapa conceitual do termo à luz dos referenciais teóricos selecionados.

Este artigo, além dessa parte introdutória, a qual situa a temática e os principais objetivos do trabalho, está organizado da seguinte forma: em primeiro lugar, apresenta-se um panorama acerca do conceito de translinguagem, Em segundo lugar, explicita-se a metodologia escolhida para a realização da pesquisa. Em terceiro, analisam-se produções acadêmicas que têm como foco a translinguagem e, para finalizar, como forma de conclusão, são apresentadas algumas considerações em relação ao estudo efetuado.

\section{TRANSLINGUAGEM: CONCEITUAÇÃO E CRÍTICAS}

O conceito de translinguagem, na atualidade, tem sido estudado na área da Sociolinguística, bem como na área da Linguística Aplicada e das Políticas Linguísticas. Williams (1994, apud GARCÍA \& WEI, 2014), foi o primeiro pesquisador a cunhar o termo Translanguaging, referindo-se a uma prática pedagógica em que os alunos alternavam entre línguas (inglês e o Welsh) para fins de uso receptivo ou produtivo. Os alunos eram convidados a ler em inglês e escrever em galês e vice-versa. Trata-se de um processo de linguagem no qual duas ou mais pessoas são capazes de usar uma ou mais línguas em uma situação comunicativa, por meio de uma mistura de idiomas, sem desconsiderar nenhuma língua presente no grupo. Falantes bilíngues, com facilidade, misturam as línguas de acordo com a situação e suas necessidades. O termo Translinguagem também remete à práticas pedagógicas que utilizam o bilinguismo como recurso possível. Neste sentido, o termo evoca uma concepção de língua não estrutural e fechada em si mesma, mas que valoriza e recupera os saberes dos falantes em suas práticas linguísticas e em prol da construção do conhecimento.

A translinguagem, concebida como um conceito para explicar o uso heteroglóssico das línguas, poderia remeter, ainda, às alternâncias linguísticas, tema bastante aprofundado na área da Sociolinguística. Porém, autores tais como Canagarajah (2013) e García \& Wei (2014) ressaltam que o termo translinguagem não se confunde com alternância linguística (ou code-switching), pois não significa somente mudar de uma língua para outra. Para esses autores, o conceito de code-switching tem em sua raiz a concepção de que as línguas dos bilíngues são dois códigos monolíngues, muitas vezes com seus usos separados e demarcados. Advogam que a 
translinguagem, por sua vez, não diz respeito apenas à mudança de uma língua para outra, mas, à construção de práticas discursivas interrelacionadas e complexas, em que as línguas e conhecimento se constituem no processo interativo, não podendo, portanto, ser atribuídas e/ou encaixadas em uma definição tradicional de linguagem.

Os estudos na área de práticas translinguísticas estão mais bem desenvolvidos em contexto britânico e americano, tanto no que se refere a trabalhos científicos quanto a materiais pedagógicos que propõem um ensino baseado na articulação de uma ou mais línguas em contexto escolar. Podem-se citar as pesquisas de Creese \& Blackledge (2010); Blommaert \& Rampton (2011) e Blommaert (2014). Fora do eixo britânico, podemos citar os trabalhos de Canagarajah (2011 e 2013) e as pesquisas de García e sua equipe tais como García \& Wei (2014), García (2018; 2019), García \& Otheguy (2019), entre outros.

O trabalho de García \& Wei (2014), por exemplo, explica as bases do conceito de translinguagem e suas implicações para a área da linguagem e do bilinguismo. Procura discutir como os entendimentos tradicionais da linguagem e do bilinguismo são transformados através da ótica da translinguagem e como esse conceito altera os entendimentos tradicionais da educação. Neste sentido, focaliza os termos tradicionais relacionados ao bilinguismo, multilinguismo e plurilinguismo, os quais, segundo os autores, foram estudados a partir de perspectivas monolíngues, para então analisar as visões mais dinâmicas desses fenômenos, argumentando que, para capturar essa complexidade, é necessário mais do que o termo linguagem. Propõem o conceito de translinguagem como uma forma de capturar práticas fluídas de linguagem dos bilíngues sem renunciar à construção social da linguagem e do bilinguismo sob o qual os falantes operam.

Lewis, Jones \& Baker (2012), ao publicar seu artigo intitulado "Translanguaging: developing its conceptualisation and contextualization" enfocam a conceitualização da translinguagem, inclusive em relação a outros conceitos já definidos voltados ao uso flexível de línguas, tal como code-switching, co-idioma e translinguagem e, depois, aos seus atributos pedagógicos e teóricos. Assim, em seu trabalho, problematizam alguns conceitos já bem delineados no campo do bilinguismo e os relacionam aos preceitos da translinguagem.

Para os autores, a introdução contemporânea do termo translinguagem levanta a questão de como esse conceito se relaciona, revela diferenças ou avança significativamente em relação a outros termos similares usados no ensino de línguas. Assim, procuram elucidar a variedade de termos explorando-os em cinco vertentes, quais sejam: a) bilinguismo dinâmico e translinguagem; b) code-switching e translinguagem $;$ c) Tradução e Translinguagem $;$ d) Co-linguagem e translinguagem, 
e) Continuum of emergent scaffolding towards translanguaging (Continuum de andaimes emergentes relativos à translinguagem), os quais são tratados a seguir.

a) Bilinguismo dinâmico e translinguagem - Existe uma diversidade de conceitos para explicar o uso concomitante de uma ou mais línguas. Os autores explicam, tendo como referência García e Kleifgen (2010) e Creese e Blackledge (2010), que a translinguagem e o bilinguismo dinâmico vão além do conceito de multicompetência. Enquanto o bilinguismo dinâmico estaria caracterizado por conceitos psicológicos e linguísticos, a translinguagem é concebida como essencialmente sociolinguística e ecológica, e só pode ser adequadamente conceituada a partir de contextos interacionais devidamente contextualizados e situados, nos quais apareçam constituintes ideológicos e de identidade de um dado contexto. García (2009) reforça que, no conceito de translinguagem, as línguas não estão separadas, pelo contrário, elas podem coexistir no mesmo espaço. Além disso, não há hierarquia entre os idiomas, como seria nos casos dos usos diglóssicos, em que uma língua se sobrepõe à outra ou tem mais ou menos poder.

b) Code-switching e translinguagem - Para os autores parece haver uma correlação entre a troca de código e a translinguagem em sala de aula. Ou seja, professores e alunos poderiam usar duas línguas em uma mesma sentença. Os autores baseiamse em Cook (2001), pesquisador que enquadra a troca de código como uma atividade altamente qualificada no "modo bilíngue", no qual uma L1 e L2 poderiam ser usadas simultaneamente. No entanto, para García (2009), a translinguagem trata de uma troca de "código responsável", que seria planejada pelo professor para melhorar habilidades cognitivas dos alunos ou reforçar uma lição. Porém, para Lewis, Jones \& Baker (2012) existe claramente uma sobreposição de conceitos entre troca de código e translinguagem, sendo o primeiro termo mais presente na área da linguística, pois se encarrega de analisar práticas bilíngues. Por outro lado, a translinguagem seria essencialmente sociolinguística, ecológica e situada. García (2009) defende que a translinguagem é mais do que a simples troca de código, pois nesta estaria implícita uma separação entre as línguas, o que não ocorreria em um contexto de translinguagem, já que o uso das línguas envolve a flexibilidade no uso da linguagem e a permeabilidade da aprendizagem através de duas ou mais línguas.

c) Tradução e Translinguagem - Lewis, Jones \& Baker (2012), explanam que os principais usos da tradução e da translinguagem se dão em salas de aula com crianças de diferentes línguas dominantes, contexto em que um professor pode traduzir de um idioma para outro, para que as crianças entendam o conteúdo em 
suas línguas. Enquanto a translinguagem estaria mais voltada ao uso simultâneo de dois idiomas, a tradução se voltaria para os usos separados de dois ou mais línguas. Lewis, Jones \& Baker (2012, p. 659) citam, por exemplo, que

Em uma sala de aula com crianças bilíngues, a tradução pode ser usada para que o idioma acadêmico mais fraco (por exemplo, inglês) usado para transmissão de conteúdo seja traduzido para o idioma mais forte (por exemplo, [a língua de] casa) das crianças para garantir a compreensão e o aprendizado de um conceito. ${ }^{4}$

Ainda, em pesquisas desenvolvidas pelos mesmos autores, esses identificaram que nos arranjos linguísticos utilizados por professores e alunos em salas de aula bilíngues no País de Gales, houve predominância de uma combinação de tradução e translinguagem. O professor trocava de idiomas, de forma seletiva, para dar instruções ou para explicar um tema. O objetivo é garantir compreensão do conteúdo entre todos os alunos. Em outras pesquisas desenvolvidas por García \& Kleifgen (2010), por exemplo, ainda que o inglês seja a língua oficial de uma disciplina, o professor fornece a essência da lição em espanhol, transmitindo uma mensagem compreensível para os bilíngues emergentes. Muitas vezes é dada uma sinopse escrita a alunos em espanhol antes que o professor comece a ensinar. Outras vezes, os materiais escritos que os professores distribuem estão em espanhol ou contêm traduções. Neste caso, a diferença entre tradução e translinguagem continua sendo que a "tradução prevê o uso de dois idiomas separados, enfatizando que um deles é preferido academicamente, mesmo que seja temporariamente a língua mais fraca. Por outro lado, a translinguagem tenta utilizar e fortalecer os dois idiomas". ${ }^{5}$ (LEWIS, JONES \& BAKER, 2012, p. 660).

d) Co-linguagem e translinguagem - $\mathrm{O}$ termo de co-linguagem também surge nas pesquisas de García, especialmente descrita em García (2009, p. 303), a qual indica "co-linguagem como um arranjo linguístico sob o termo genérico de 'translinguaegm" (apud LEWIS, JONES \& BAKER, 2012, p. 660). Para esta pesquisadora, tal arranjo ocorre quando o conteúdo curricular é ensinado à diferentes grupos linguísticos simultaneamente. Também, a co-linguagem pode ser potencializada quando alunos de escola primária, por exemplo, escutam leituras de livros em diferentes idiomas. Outro exemplo seria por meio de

4. (Esta e todas as traduções não referenciadas são de minha autoria). In a classroom with bilingual children, translation may be used so that the weaker academic language (e.g., English) used for content ally even if it is temporarily the weaker language. In contrast, translanguaging attempts to utilize and strengthen both languages.

5. Translation tends to separate languages, emphasising that one language is preferred academically even if it is temporarily the weaker language. In contrast, translanguaging attempts to utilize and strengthen both languages. 
tecnologias aplicadas à educação: uma apresentação em PowerPoint poderia apresentar duas línguas na tela, usando o mesmo conteúdo, mas em cor ou fonte diferente para cada idioma.

e) Continuidade de andaimes emergentes relativos à translinguagem (Continuum of emergent scaffolding towards translanguaging) - O termo "andaime" é comumente utilizado para explicar um processo de suporte na aprendizagem de línguas. No caso explorado pelos autores, especialmente a partir da pesquisa de García (2009), o andaime é frequentemente necessário para apoiar alunos bilíngues nos estágios iniciais do sua aprendizagem, usando uma segunda língua no processo de ensino-aprendizagem. Neste caso, Lewis, Jones \& Baker (2012) descrevem como estratégias de andaime o apoio contextual e linguístico, construção de esquemas ou planejamento temático.

Ao apresentar a discussão de termos da linguística em relação ao viés da translinguagem, os autores questionam se todos se referem aos mesmos processos ou entre eles haveria alguma diferença. Neste sentido, os autores asseveram que

a translinguagem como um conceito se difere suficientemente da troca de código e da tradução, por isso requer sua própria definição e uso em desenvolvimento. Não apenas possui funções diferentes da troca de código e da tradução, mas também o termo foi desenvolvido para envolver, ser situado e ser sociolinguistico. Assim, a compreensão da translinguagem requer que ela tenha contexto e não apenas conteúdo, atividade cognitiva e cerebral e não apenas sobre código linguístico, bem como opere continuamente e não apenas nas salas de aula. No entanto, a translinguagem é um conceito educacional emergente, com explicação, pesquisa e contextualização principalmente na sala de aula. (LEWIS, JONES \& BAKER, 2012, p. 667$)^{6}$

Portanto, os autores defendem a perspectiva da translinguagem, ancorados nos trabalhos de García (2009 e outros). Para Lewis, Jones \& Baker (2012), a teoria pedagógica da translinguagem desafia a crença na separação de idiomas em um processo educacional bilíngue. É uma teoria que focaliza os processos bilíngues de aprendizagem em vez de apenas centrar-se em resultados bilíngues. Além disso, citam o fator ideológico envolvido no conceito de translinguagem, pois sua aplicação exige um movimento que vai desde a formação docente até o trabalho

6. That translanguaging as a concept is sufficiently different from code-switching and translation to require its own developing definition and usage. Not only does it have different functions from code-switching and translation, but also the term has been developed to engage, be situated and sociolinguistic. Thus, understanding of translanguaging requires it to have context and not just content, cognitive and cerebral activity and not just about linguistic code, and operate continuously and not just in classrooms. However, translanguaging is an emergent educational concept with its explication, research, and contextualization being mainly in the classroom. 
com a educação bilíngue nas salas de aula. Requer, portanto, uma abordagem multi e interdisciplinar.

Desse modo, podemos observar que os autores concordam com os postulados de García e Wei (2014), quando argumentam que o code-switching e a translinguagem são diferentes, pois, no caso do code-switching, tomam como ponto de partida de gramáticas separadas para cada um dos idiomas e a translinguagem concentra-se nas práticas linguísticas usadas na comunicação bilíngue. Do mesmo modo, Cenoz (2017), tendo como base os estudos desenvolvidos por García e outros, defende que a translinguagem implica uma conceitualização holística do bilinguismo e multilinguismo e pode ser entendida como parte de um paradigma emergente no estudo do bi/multilinguismo e na área de aquisição de linguagem. Esse paradigma, portanto, implica em uma nova concepção sobre linguagem, de seus falantes e repertórios. Segundo ressalta a pesquisadora, as fronteiras entre os idiomas estão se tornando mais suaves e as especificidades do falante multilíngue são vistos como um recurso importante.

Por outro lado, em que pese todos os argumentos relacionados ao caráter transformar da translinguagem, este conceito, considerado como prática ou como pedagogia, também levanta algumas críticas no cenário acadêmico. A mais contundente vem do trabalho de Jaspers (2017), o qual declara que "a translinguagem pode ser menos transformadora e crítica do que geralmente poderia sugerir" (2017, p. 2). Em vista disso, destaca uma série de tensões que para ele envolvem o conceito de translinguagem, sobretudo, em relação aos trabalhos realizados por García e sua equipe. Em primeiro lugar, o autor faz críticas à própria noção de translinguagem, como sendo um conceito amplo, em suas palavras "uma casa terminológica com muitos quartos" (JASPERS, 2017, p. 3). Neste sentido, a amplitude de eixos que envolve a translinguagem dificultaria a sua consolidação como um conceito. No mesmo viés, o artigo de Conteh (2018), ao tratar da definição do termo, afirma que existem questionamentos em relação à translinguagem, tendo em vista a necessidade de um novo conceito quando os familiares já existentes, nomeados como troca de código e mistura de código, já fornecem uma estrutura com a qual é possivel entender o uso da linguagem multilíngue.

Outro elemento destacado por Jaspers (2017) refere-se à translinguagem como um construto que se centra na ideia de desempenho e exclui os falantes "monolíngues", ao se pautar apenas nos falantes bilíngues, já que a translinguagem contempla "as múltiplas práticas discursivas nas quais os bilíngues se envolvem para entender seus mundos bilíngues" (JASPERS, 2017, p. 4 apud GARCÍA e WEI 2014, p. 65). Ainda, segundo Jaspers, uma definição mais ampla, incluindo monolíngues, 
sugere que a translinguagem implica a implantação de todo o repertório linguístico de um falante, sem levar em consideração a observância atenta aos limites social e politicamente definidos das línguas nomeadas.

Em relação às suas afirmações, seria importante mencionar o trabalho Blackledge \& Creese (2014), portanto, anterior ao artigo de Jaspers, os quais, por meio de suas pesquisas, manifestavam-se em relação a esta controversa questão a respeito de indivíduos monolíngues e bilíngues. Os autores argumentam que muitas vezes fazem-se falsas distinções entre os chamados indivíduos monolíngues, bilíngues e multilíngues e sugerem que, em certo sentido, somos todos multilíngues, tendo à nossa disposição uma variedade de maneiras de usar a linguagem, mesmo que falemos apenas uma língua e escrevamos em uma "linguagem" específica.

Outra crítica está relacionada ao fato de alguns autores pontuarem a translinguagem como um potencial projeto de transformação política, pessoal e social, transformadora a ponto de mudar as subjetividades dos alunos, suas estruturas cognitivas e sociais, além de atribuir o fracasso escolar à incapacidade das escolas de validar essas subjetividades bilíngues. Para o autor, tratam-se de alegações bastante ambiciosas, pois

sugere-se que a translinguagem (como pedagogia e prática) resulte em novas subjetividades, devolva a voz, transforme estruturas cognitivas, aumente os níveis de bem-estar e de realização e, finalmente, transforme uma sociedade desigual em um mundo mais justo. Isso seria esperar muito sobre a introdução de práticas linguísticas específicas na escola, e é uma questão de honestidade intelectual indagar se podemos confiar nos efeitos previstos. (JASPERS, 2017, p. 6$)^{7}$

Além dessa crítica, Jaspers (2017) cita a questão da justiça social, ao conectar a translinguagem à agenda linguística dos direitos humanos, além de incentivar, pelas práticas translíngues, a instituição do uso da língua não padrão. Para Jaspers, o conceito de translinguagem se reveste de características camaleônicas, fato também criticado por Pavlenko (2017), sobretudo questionando a que agenda o conceito de translinguagem estaria servindo ao tentar reunir tantos atributos em um só termo.

$\mathrm{Na}$ sequência, sua crítica recai em torno do papel dos professores ao trabalharem em uma perspectiva de translinguagem. Tomando excertos dos trabalhos de García e Wei (2014, p. 122-123), os quais afirmam que todos os professores deveriam estar preparados para serem professores para trabalhar em uma

7. Translanguaging (as pedagogy and practice) is suggested to result in new subjectivities, to give back voice, transform cognitive structures, raise well-being and attainment levels, and eventually to transform an unequal society into a more just world. This is expecting a lot from the introduction of specific linguistic practices at school, and it is a matter of intellectual honesty to inquire if we can rely on the predicted effects. 
perspectiva bilíngue ou da translinguagem e, por meio de suas práticas, desenvolver as línguas adicionais dos alunos enquanto os ensinam, Jaspers pergunta sobre como e porque os professores deveriam se adaptar a este projeto bem como qual seria o papel de alunos, colegas, diretores de escola em relação à instituição dessa forma de se trabalhar a língua nas escolas. Jaspers (2017) rebate seus questionamentos ao afirmar que há muito valor nesta perspectiva, ressaltando que a diversidade linguística nas aulas está mais sintonizada com valores democráticos, porém, para o autor, sobretudo no ensino superior, o processo de ensino segue uma dinâmica monolíngue e que em raras exceções seria empregado outro registro de língua a não ser o acadêmico.

Neste sentido, o autor lança um debate em relação às dinâmicas do monolinguismo e do multilinguismo no ambiente acadêmico. Segundo sua perspectiva, "as práticas de translinguagem podem ser valiosas e amigáveis aos alunos" (pg. 10), porém elas podem ser menos importantes do que a capacidade de que os alunos se desenvolvam em registros acadêmicos com mais valor social. Assim, lança duas perguntas: a primeira sobre "como valorizar a diversidade linguística dos alunos sem perder de vista os registros socialmente monolíngues" e a segunda, "como fazer com que os alunos aprendam um registro coletivamente valorizado, sem sugerir que suas habilidades linguísticas individuais são menos importantes?" " $^{\prime 8}$ (p.10). Segundo Jaspers (2017), para resolver esses dilemas,

os professores, às vezes recorrem a estratégias improvisadas, promovendo a translinguagem durante o trabalho em grupo, por exemplo, mas desaprovam sua ocorrência em outros contextos (por escrito, no ensino superior) (Martínez, Hikida e Durán 2015); outros professores insistem explicitamente em uma política monolíngue, mas na prática reconhecem e até usam as variedades domésticas dos alunos (Op.cit., p. 10).9

O trabalho de Jaspers (2017) levanta essa série de questões que podem e devem ser consideradas ao se tratar do conceito de translinguagem, sobretudo, pela amplitude de elementos que envolvem o conceito. Porém, ao realizar uma detalhada pesquisa a respeito de trabalhos acadêmicos publicados tendo este viés conceitual, sua crítica parece apresentar-se de forma isolada.

8. "How do you valorize pupils' linguistic diversity without losing sight of socially valued, monolingual, registers? Or, inversely, how do you make pupils learn a collectively valued register without implying that their individual linguistic skills are less important? (Jaspers, 2017, p. 10).

9. To resolve this teachers sometimes resort to makeshift strategies, promoting translanguaging during group-work, for example, but frowning upon its occurrence in other contexts (in writing, in higher education) (Martínez, Hikida, and Durán 2015); other teachers explicitly insist on a monolingual policy but in practice recognize and even use pupils' home varieties [Jaspers, 2015]. (JASPERS, 2017, p. 10). 
Muitas outras pesquisas e trabalhos foram e continuam sendo publicados, fato que de certa forma mostra sua importância para descrever práticas híbridas de linguagem, sobretudo, em ambiente escolar (cf. CENOZ, 2017; GARCÍA, 2018; DUARTE, 2019). Deste modo, a translinguagem revela-se não só como um conceito que envolve a prática e o ensino de línguas, mas um campo de conhecimento na área da linguagem, já que problematiza a noção de língua, a noção de falante monolíngue e bilíngue, bem como o papel das línguas na escola e na formação docente.

Em vista do exposto, podemos considerar que os estudos na área da translinguagem, em que pese algumas críticas relacionadas à amplitude do termo, têm em comum a defesa por uma pedagogia multilíngue e que leve em conta as línguas presentes no entorno social, sobretudo, as línguas presentes no ambiente escolar. Ou seja, advogam que a escola deveria ser um espaço para o convívio entre as línguas e que o conhecimento de mais de uma língua não deveria ser empecilho para o processo de aprendizagem, mas sim um facilitador.

\section{OPÇÃO METODOLÓGICA}

O método que conduz o estudo ora proposto está embasado na pesquisa qualitativa conforme proposto por Denzin \& Lincoln (2006). Como instrumentos de pesquisa nos utilizamos da pesquisa bibliográfica para o levantamento produções acadêmicas inseridas no viés da translinguagem. Assim, para a busca desses trabalhos nos valemos da pesquisa em revistas especializadas da área da linguística e da sociolinguística, considerando publicações nacionais e internacionais. Também nos baseamos em alguns pressupostos da etnografia linguística sendo que esta "é uma abordagem interpretativa que estuda as ações locais e imediatas dos atores do ponto de vista deles e considera como essas interações são incorporadas em contextos e estruturas sociais mais amplas", conforme Copland \& Creese (2015, pg. 29). Assim, nos interessa o olhar da etnografia linguística, pois nos permite questionar e compreender como a linguagem afeta os processos sociais e, de outro lado, como os processos sociais afetam o uso dos recursos linguísticos.

Para que se tenha um panorama dos textos escolhidos, na tabela a seguir, estes são apresentados cronologicamente, primeiramente os publicados em contexto estrangeiro e, em segundo lugar, os publicados em contexto brasileiro. Foram escolhidos 10 artigos entre os muitos trabalhos encontrados, tendo como critério de escolha os que atendiam ao objetivo do estudo. Assim, o conceito de translinguagem deveria aparecer como uma teoria de base para a descrição dos fenômenos discutidos em cada pesquisa. 
Tabela 1. Textos selecionados para análise

\begin{tabular}{|l|l|l|}
\hline \multicolumn{2}{|l|}{ CONTEXTO ESTRANGEIRO } & TÍTULO \\
\hline AUTOR(ES)/ANO & CREESE \& BLACKLADGE (2010) & $\begin{array}{l}\text { Translanguaging in the Bilingual Classroom: A } \\
\text { Pedagogy for Learning and Teaching? }\end{array}$ \\
\hline 01 & SMITH, ET ALL (2017) & A Pedagogy for bi/plurilingual pupils: Translanguaging \\
\hline 03 & JONES (2017) & Translanguaging in Bilingual Schools in Wales \\
\hline 04 & WEI (2018) & Translanguaging as a Practical Theory of Language \\
\hline 05 & JONSSON (2019) & $\begin{array}{l}\text { 'What is it called in Spanish?': Parallel } \\
\text { Monolingualisms and translingual classroom talk }\end{array}$ \\
\hline CONTEXTO BRASILEIRO & ROCHA \& MACIEL (2015) & $\begin{array}{l}\text { Ensino de língua estrangeira como prática translíngue: } \\
\text { articulações com teorizações bakhtinianas }\end{array}$ \\
\hline 06 & $\begin{array}{l}\text { As práticas translíngues emergentes nas aulas de } \\
\text { escola da fronteira Brasil-Bolívia: negociação de } \\
\text { sentidos e justiça social }\end{array}$ \\
\hline 07 & FERRARI (2016) & $\begin{array}{l}\text { "Portunhol Selvagem": translinguagens em cenário } \\
\text { translíngue/transcultural de fronteira }\end{array}$ \\
\hline 08 & SANTOS (2017) & $\begin{array}{l}\text { "Eles començam sanguear": translinguagem como } \\
\text { prática criativa e de construção de conhecimento em } \\
\text { português língua estrangeira }\end{array}$ \\
\hline 09 & MILOZO \& GATTOLIN (2019) \\
\hline 10 & $\begin{array}{l}\text { OLflexões sobre o ensino de português como língua } \\
\text { de acolhimento pelo viés da pedagogia translanguaging }\end{array}$ \\
\hline
\end{tabular}

Sendo assim, procedemos à seleção dos trabalhos que faziam alusão à concepção do termo e de suas bases teóricas, bem como aqueles que apresentavam análises de situações consideradas pertencentes ao escopo da translinguagem. Igualmente, considerando os objetivos do presente estudo, optamos por realizar um panorama, por meio de uma descrição qualitativa dos textos selecionados.

\section{AS PESQUISAS EM TRANSLINGUAGEM DESENVOLVIDAS EM CONTEXTO ESTRANGEIRO E BRASILEIRO}

Para iniciar a análise, o artigo de Creese \& Blackladge (2010) aponta para a translinguagem como uma pedagogia para ensinar e aprender. Questiona as estratégias de ensino baseadas no monolinguismo e considera que, ao trabalhar em um contexto multilinguístico e usar de estratégias monolíngues constitui-se em um desperdício de recursos linguísticos e de conhecimento. $\mathrm{O}$ artigo baseia-se em 
uma perspectiva ecológica do multilinguismo (HORNEBERGER, 2002), o qual em sua essência versa sobre a abertura ideológica para que sejam usadas tantas línguas quanto possíveis no ambiente social/escolar. Em seu cerne está a dialética entre o que é local/social e interacional/ideológico. Por meio de uma abordagem ecológica da linguagem é possível estudar a ordem interacional bem como são criadas e implementadas as ideologias sociais em relação ao multilinguismo (CREESE \& BLACKLADGE, 2010).

A pesquisa em destaque descreve um estudo de caso, baseado em etnografias da sala de aula, referente ao um projeto maior, em escolas complementares no Reino Unido, as quais têm o gujarati ${ }^{10}$ e chinês como línguas do contexto. As aulas descritas são realizadas em diferentes dias da semana (sábado, domingo, quintafeira à noite) e se reúnem em média de 2 a 3 horas por semana. O número de estudantes presentes nas escolas chinesas e gujarati varia entre 200 e 350 , tendo em média em torno de 5 a 35 professores voluntários.

Por meio do projeto proposto, os alunos desenvolveram alguns conhecimentos e habilidades específicas, os quais mostram como é possível praticar uma forma flexível de bilinguismo. Entre esses conhecimentos e habilidades estão as práticas bilíngues por meio de repetições e traduções entre idiomas; capacidade de envolver o público através da transliteração e heteroglossia; uso de translinguagem para estabelecer posições de identidade e valores institucionais; reconhecimento de que as línguas não se encaixam em entidades delimitadas claras e que todas as línguas são "necessárias" para que os significados sejam transmitidos e negociados; uso das línguas simultaneamente para manter as tarefas pedagógicas em movimento; reconhecimento de que professores e alunos podem usar suas línguas para diferentes objetivos, tais como narração e explicação; uso de translinguagem para anotação de textos, proporcionando maior acesso ao currículo e realização de lições. (CREESE \& BLACKLADEGE, 2010, p. 112 e 113). Assim, por meio deste estudo de caso, os autores defendem a instrução bilíngue, baseada na perspectiva da translinguagem, como uma saída para o desenvolvimento de um processo de ensino mais inclusivo, mais participativo e motivador para professores e alunos.

10. “O gujarati ou guzerate, é uma língua indo-ariana e um dos 22 idiomas oficiais da Índia, além de ser considerada uma língua minoritária do Paquistão. Cerca de 46 milhões de pessoas falam o guzerate, o que o faz a $23^{\mathrm{a}}$ língua mais falada no mundo. Destes, aproximadamente 45.5 milhões vivem na Índia. O idioma é a principal língua do estado indiano do Guzerate, bem como dos territórios federais adjacentes de Damão, Diu, Dadrá, Nagar-Aveli. É também o idioma da numerosa comunidade guzerate de Bombaim. Além da Índia, o Guzerate é falada em Uganda (150 mil pessoas), na Tanzânia (250 mil pessoas), Quênia (50 mil pessoas ) e Paquistão (100 mil pessoas). Há também um grande contingente de falantes de guzerate na América do Norte e no Reino Unido". Disponível em: https://www.apolo11.com/linguas.php?li=gujarati. Acesso em 23 jan. 2020. 
No campo da translinguagem também articulada à prática, o segundo trabalho tomado para análise trata-se de um livro publicado pela Universidade de Newcastle que tem como título: A Pedagogy for bi/plurilingual pupils: Translanguaging (SMITH; et all, 2017). Constitui-se de um Guia do Professor e é resultado de um projeto $^{11}$ desenvolvido em quatro países europeus: Reino Unido, França, Finlândia e Romênia, tendo a duração de dois anos e meio. O objetivo geral do projeto foi melhorar a educação de crianças imigrantes de origem europeia na escola primária (idade 5-11) em salas de aula em toda a Europa e em uma escola secundária na França (com alunos até 15 anos), com vistas a melhorar o envolvimento e motivação do aluno, com o objetivo final de aprimorar a aprendizagem. Segundo os autores do material, o projeto foi desenvolvido em resposta às lacunas persistentes no atendimento escolar de alunos imigrantes, bem como ao declínio (ou inexistência) do uso da sua língua materna ou de origem nas salas de aula de seu atual país de moradia. Assim, o projeto, por meio do uso de práticas translíngues, constituiu-se de uma ferramenta pedagógica para aumentar o desempenho acadêmico de alunos cuja língua(s) doméstica(s) difere da língua oficial da escola.

As premissas teóricas que regem o documento analisado seguem os postulados de García (2009) e Wei (2011), para os quais a língua em vez de um objeto linguístico, é um verbo, um ato social, é resultado de um processo. Também, segue os postulados de Coste, Moore \& Zarate (1997), estudiosos da área do plurilinguismo, os quais designam este conceito como a capacidade de uso de diferentes línguas para fins de comunicação, para participar em intercâmbios interculturais e no qual o falante é visto como um ator social, o qual pode contar com diferentes graus de proficiência nas línguas de um dado contexto. Já a translinguagem é defendida como uma pedagogia, na qual incidem uma teoria sociocultural de aprendizagem, os pressupostos do plurilinguismo e de educação transformadora.

Outro aspecto bastante importante deste documento é o fato de reconhecer a existência de relações de poder entre os interlocutores e suas línguas, sendo este aspecto uma das dimensões da translinguagem como uma pedagogia de ensinar e aprender. Segundo Smith et all (2017, p. 11), citando o trabalho de García (2009)

As línguas de um indivíduo raramente são socialmente iguais, tendo poder e prestígio diferentes, e elas são usadas para diferentes propósitos, em diferentes contextos, com diferentes interlocutores. (GARCÍA, 2009, p.45) ${ }^{12}$.

11. Trata-se do projeto ROMtels (Roma translanguaging enquiry learning space), desenvolvido pela Universidade de Newcastle - U.K. https://research.ncl.ac.uk/romtels/.

12." The languages of an individual are rarely socially equal, having different power and prestige, and they are used for different purposes, in different contexts, with different interlocutors." 
Neste sentido, reforçam que um trabalho voltado exclusivamente à variedade padrão de uma língua oculta outras práticas linguísticas e línguas igualmente relevantes e que, em muitos casos, são parte da identidade linguísticas dos aprendizes.

O terceiro trabalho escolhido para análise trata-se do artigo de Jones (2017) no qual o uso da translinguagem aparece como uma ferramenta pedagógica de apoio em salas de aula bilíngues nas escolas do País de Gales. Assim, o seu artigo trata do uso da translinguagem em um contexto da educação bilíngue inglês-galês. $\mathrm{O}$ galês é uma das línguas minoritárias regionais da Inglaterra, oficialmente reconhecida e usada na educação. Neste artigo, Jones analisa a situação bilíngue no País de Gales e o uso da translinguagem em contexto escolar.

Jones (2017), em seu artigo Translanguaging in bilingual schools in Wales destaca que a educação bilíngue no País de Gales, a qual envolve o inglês e o galês abarca uma variedade de práticas em que os idiomas são frequentemente separados nas atividades de ensino e aprendizagem ou são usados de maneira flexível um com o outro. Segundo o autor, embora o País de Gales tenha uma tradição progressista na educação bilíngue, em sala de aula, tende a certo grau de separação de idiomas em vez de uma abordagem direcionada à translinguagem. Assim, o autor apresenta os seguintes arranjos que pode ter a educação bilíngue no País de Gales: (1) Aprendendo através de dois idiomas. Isso pode incluir: (a) bilinguismo separado (usando um idioma por vez na sala de aula para promover o bilinguismo) - por exemplo, oferecendo alguns assuntos em galês e outros em inglês ou apresentando um módulo em galês e o seguinte módulo em inglês; - ou (b) bilinguismo flexível (usando dois ou mais idiomas na sala de aula) - por exemplo, translinguagem - e (2) Aprendendo em um idioma - por exemplo, salas de aula separadas para galês e inglês ou grupos de galês e de inglês médio dentro da mesma classe (co-idioma). (JONES, 2017, p. 202).

Deste modo, segundo os autores, o modelo galês apresenta basicamente dois modelos de uso da linguagem em sala de aula, segundo pesquisa desenvolvida por Jones (2010): o primeiro modelo pode ser classificado como translinguagem dirigida pelo professor (que pode ser descrita como uma atividade planejada pelo professor para bilíngues emergentes e mais competentes). Para bilíngues emergentes, o professor tenta organizar a atividade envolvendo a translinguagem, por exemplo, escolhendo material de leitura apropriado e fornecendo proposta de escrita. Foi observado em algumas salas de aula bilíngues do país de Gales que o professor apresentou "dicas de translinguagem" (p.204) para instruir alunos emergentes e competentes como concluir as atividades de translinguagem (Jones \& Lewis, 2014). 
O professor forneceu "pistas" (oralmente, por escrito ou ambos) para indicar o idioma de destino para o desenvolvimento de habilidades de linguagem receptivas e para o desenvolvimento de habilidades de linguagem produtivas.

O segundo modelo pode ser classificado como translinguagem direcionada ao aluno (classificada como atividades de translinguagem realizadas de forma independente por bilíngues mais competentes). Os alunos trabalham de maneira independente e escolhem como concluir a atividade, por exemplo, reunir informações da Internet em inglês, discutir o conteúdo em galês e concluir o trabalho escrito em galês.

Na sequencia o autor discorre sobre o uso da translinguagem na educação primária e secundária de Gales, ao apresentar lições e exemplos de atividades que são conduzidas pelos professores nas quais se evidencia o uso alternado de línguas. Neste sentido, o autor reforça que em ambas as etapas da escolarização a translinguagem é usada como uma pedagogia tanto de input (para desenvolver habilidade de ouvir / ler / recordar) e de output (para desenvolver habilidades produtivas de linguagem: falar / escrever/cantar). Por meio de sua pesquisa, Jones (2017) buscou evidenciar que a translinguagem constitui-se em uma pedagogia para ensinar línguas no País de Gales. Destaca o papel progressista na educação bilíngue nesta região do Reino Unido e menciona certa proteção à língua galesa nas atividades linguísticas escolares, portanto, a translinguagem atua como forma de manutenção da língua minoritária.

No entanto, ao mesmo tempo em que ressalta o papel da translinguagem como uma ferramenta para a manutenção das línguas, chama a atenção para o fato de que há uma escassez de pesquisas que envolvam outras salas de aula com alunos de outras minorias étnicas, bem como questiona até que ponto a translinguagem, efetivamente, pode fortalecer as práticas em galês para alunos emergentes e se os professores estariam convencidos dos benefícios e das possibilidades do uso da translinguagem em suas práticas pedagógicas.

O quarto trabalho analisado trata-se do artigo de Wei (2018), o qual tem como objetivo central esclarecer o uso do termo translinguagem - sendo este considerado pelo autor como uma teoria prática da linguagem. Tal artigo tem sua justificativa baseada no que Wei $(2018$, p. 9) designa de confusão causada pelo uso do termo. Segundo o autor:

O crescente corpo de trabalhos dá a impressão de que qualquer prática que seja ligeiramente não convencional pode ser descrita em termos de Translinguagem Há uma considerável confusão sobre se a Translinguagem pode ser um termo abrangente para diversas práticas multilingues e multimodais, substituindo termos como code-switching, code-mixing, codemeshing e crossing. Parece, também, estar em competição com outros termos, por exemplo, 
polilinguagem, linguagem polilinguística, multilinguismo, heteroglossia, práticas linguísticas híbridas, práticas translíngues, bilinguismo flexível e metrolingualismo, presentes no espaço do discurso acadêmico (Op.Cit., p. 9). ${ }^{13}$

Wei (2018) destaca que há muitas outras práticas linguísticas dinâmicas e criativas que envolvem o uso de várias línguas. Porém, para o autor, é importante observar que muitas abordagens são excessivamente simplistas ou inadequadas para descrever ou analisar as complexas realidades linguísticas do século 21 (XXI). Ainda que se tenha havido progressos significativos no tocante à compreensão das realidades multilingues, em muitas partes do mundo, ainda não o é a mistura de idiomas, já que ainda paira o mito de uma forma pura de língua e, muitas pessoas, não aceitam a "contaminação da sua língua por outras" (WEI, 2018, p. 14).

Neste caso em particular, baseia-se na situação do "Chinglish" (mistura entre chinês e inglês), por esta ter sido objeto de ridicularização por muito tempo. Tal relato assemelha-se muito ao que vivem diversos falantes bilíngues em território brasileiro. Wei (2018) ainda ressalta que o termo translinguagem não foi originalmente concebido como um conceito teórico, mas um rótulo descritivo para uma prática de linguagem específica, tal como apresentado anteriormente ao citar a prática desenvolvida por Willimas (1994).

Ao longo dos anos, o conceito de translinguagem provou ser uma ferramenta eficaz de prática pedagógica em uma variedade de contextos educativos em que a língua da escola ou a língua de instrução é diferente das línguas dos alunos, pois, deliberadamente, quebra as divisões artificiais e ideológicas entre, por exemplo, maioria versus minoria; língua meta versus língua materna. A translinguagem empodera tanto o aluno quanto o professor, transforma as relações de poder, e possibilita que o processo de ensinar e aprender comece a fazer sentido, melhore a experiência e desenvolva identidades (WEI, 2018, apud GARCÍA, 2009; CREESE \& BLACKLEDGE, 2015).

Ainda, o autor ressalta que o conceito de translinguagem não deve ser concebido como um objeto ou um fenômeno linguístico passível de descrição e análise, mas como uma prática e um processo - uma prática que envolve uma dinâmica integrada de diferentes línguas e variedades linguísticas e que vai além disso: trata-se de um processo de construção do conhecimento que amplia a noção de língua/gem(s). Salienta, ainda, que a translinguagem nunca pretendeu substituir o que se consagrou como troca de código ou termos assemelhados, embora desafie a noção de código linguístico.

13. Esta e todas as traduções não referenciadas são de minha autoria. 
Assim, em última instância, a translinguagem é uma perspectiva que desafia as abordagens ligadas ao multilinguismo. Wei (2018) define a translinguagem como uma Teoria Prática da Linguagem, situada no viés da Linguística Aplicada, e que tem como preocupação entender as criativas e dinâmicas práticas de linguagem. Neste sentido, o trabalho de Wei (2018) reforça que o termo translinguagem, mais do que um conceito, é uma forma pela qual se pode ensinar e aprender línguas.

Por fim, o quinto artigo escolhido para análise é o trabalho de Jonsson (2019) 'What is it called in spanish?': Parallel monolingualisms and translingual classroom talk o qual apresenta uma pesquisa realizada em uma escola bilíngue na Suécia, com crianças do $5^{\circ}$ ano da educação primária. Em sua pesquisa, argumenta que, em uma escola bilíngue, os recursos linguísticos e semióticos dos alunos que falam um, dois ou vários idiomas podem ser usados no discurso em sala de aula, a fim de abraçar e fortalecer a multiplicidade de vozes e línguas no ensino e aprendizagem. Em seu trabalho analisa quatro sessões de língua inglesa como meio de instrução (EMI), em que as línguas oscilam entre o sueco, o inglês e o espanhol e sobre como a translinguagem pode ser usada como um recurso pedagógico em sala de aula. Em sua pesquisa, buscou responder às seguintes questões: a) como os alunos e seus professores usam a linguagem e recursos semióticos durante as aulas de inglês; b) que oportunidades de uso de translinguagem como pedagogia da aprendizagem de línguas existem durante essas lições; e c) o que os aspectos visuais da sala de aula revelam sobre o uso da linguagem e da translinguagem (p. 323).

Segundo a autora, apesar de cerca de 200 idiomas serem falados na Suécia e apesar das diferentes iniciativas que foram tomadas para apoiar a realidade multilíngue naquele país, como o Language Act (2009) ${ }^{14}$, a norma monolíngue ainda prevalece fortemente na sociedade sueca. Essas normas também estão presentes em escolas bilíngues, em que os idiomas são implementados em um continuum monolínguismo - bilinguismo. No entanto, em sua opinião, seria possível optar por uma abordagem multilíngue, em que a translinguagem também poderia ser usada como uma pedagogia para a aprendizagem de idiomas.

A pesquisa foi realizada em uma escola sueca independente, na qual o ensino era realizado em sueco e espanhol. A política linguística da escola centra-se na noção de bilinguismo, por isso, além de ter as atividades em sueco, também, oferece aulas em espanhol. Ainda, como características da escola onde o estudo foi desenvolvido, o espanhol era apenas programado para ser usado durante três aulas por semana. Em suma, o espanhol, que é a língua materna de alguns alunos da escola e uma língua

14. Disponível em: <https:/www.regeringen.se/contentassets/9e56b0c78cb5447b968a29dd14a68358/ spraklag-pa-engelska>. Acesso em 12 de nov. 2020. 
estrangeira para os demais alunos, foi alocado em 245 minutos por semana. Esse valor pode ser comparado ao inglês, que é considerada uma língua estrangeira e que foi atribuída a esta língua 160 minutos por semana. O restante do currículo é realizado em sueco. Os alunos estudam espanhol por meio de diferentes disciplinas, tais como Matemática, Ciências e Estudos Sociais. Isso significa que as aulas de espanhol não são aulas de espanhol por si só, mas aulas de diferentes disciplinas ministradas em espanhol. O sueco também é língua base das disciplinas curriculares, tais como Matemática, Ciências, Estudos Sociais, Educação Física, Arte, Esportes e Música. Já o inglês, é estudado somente por meio de aulas de língua.

Ainda descrevendo o contexto de sua pesquisa, Jonsson (2019) ressalta que, na escola, os professores que ensinam espanhol também falam sueco, por outro lado, os professores que ensinam sueco não falam necessariamente espanhol, ou apenas falam um pouco de espanhol. Avalia, portanto, que isso pode ser visto como um sinal de desigualdade que existe na escola, podendo ser "considerado como 'monolinguismo paralelo' (Heller, 1999) ou 'norma de monolinguismo duplo' na escola (Jørgensen, 2008)". (JONSSON, 2019, p. 328).

Ao analisar os dados de sua pesquisa, Jonsson (2019) observou que a maioria dos textos e materiais de ensino, bem como o texto do professor dentro e fora do quadro, eram monolíngues ou escritos como monolinguismos paralelos, conforme a norma do monolinguismo ou do monolinguismo duplo. Já as conversações em sala de aula, por outro lado, eram de natureza mais translingual, embora também incluísse monolinguismo. Observou, também, que a professora da turma tinha o poder de decidir quando e como recursos de translinguagem seriam usados, conforme descrição a seguir:

Às vezes, ela costumava usar práticas de policiamento de idiomas (cf. Amir e Musk 2013) para fazer com que os alunos usassem o idioma de destino inglês, por ex. "Você não consegue dizer isso em inglês?" (Lição de inglês 23 de maio de 2011), enquanto em outras ocasiões ela permitia comparações não apenas com o sueco, mas também com o espanhol. (JONSSON, 2019$, p.333 $)^{15}$

Neste sentido, considera que, no geral, os rótulos de idiomas, especialmente 'sueco' e 'inglês', foram usados com frequência durante as aulas. A professora ainda se utilizou de muitos recursos de tradução nas aulas, bem como do apoio do livro didático, que continha glossário em sueco para a explicação dos conteúdos.

15. At times, she used language policing practices (cf. Amir and Musk 2013) to make the students use the target language English, e.g. 'Can't you say it in English?' (English language lesson May 23rd, 2011), whereas at other times she allowed for comparisons not only to Swedish, but also to Spanish. 
Portanto, conclui que, na escola, embora tenha um perfil bilíngue/multilíngue, as línguas são mantidas separadas como monolinguismo paralelo. Outro detalhe está nas competências linguísticas dos professores da escola que, em muitos casos, são vistas como separadas, no sentido de que se espera que os professores que usam o espanhol como principal meio de ensino devem entender e falar sueco, enquanto o mesmo não é esperado dos professores de sueco e outras disciplinas, dos quais não necessariamente se espera que devam entender ou falar espanhol. Segundo a pesquisadora, este desequilíbrio tem consequências para uso da língua na sala de aula, bem como em reuniões entre os professores e os pais. Por outro lado, a pesquisadora observa que a translinguagem é uma prática empregada tanto pelo professor quanto pelos alunos e os resultados mostram que há certa luta entre a translinguagem em sala de aula e o monolinguismo paralelo. Ainda, ressalta que o seu estudo mostra o poder dos professores para decidir quando usar recursos da translinguagem ou não.

No Brasil, são recentes os estudos que se referem à translinguagem. Entre as pesquisas publicadas em contexto brasileiro, nessa área, selecionamos cinco artigos, conforme a tabela anterior (Tabela 1). Os trabalhos datam de 2015 a 2019 e articulam-se à translinguagem tanto como teoria que reinaugura a conceitualização do uso híbrido das línguas quanto como uma metodologia para ensinar línguas.

Como forma de apresentar os artigos selecionados, destacamos que o primeiro se detém em analisar e situar teoricamente o tema; o segundo faz uma análise pautada em um contexto de fronteira, em que o português e o espanhol convergem, o terceiro apresenta um estudo de caso em que a prática translinguística ocorre entre o português, o espanhol e variedades do guarani, também em contexto de fronteira. Os artigos analisados em quarto e quinto lugar versam acerca do conceito de translinguagem aplicado ao ensino de português, tanto como língua estrangeira, tanto como língua de acolhimento.

O trabalho de Rocha e Maciel (2015) faz uma leitura do termo translinguagem à luz do construto bakhtiniano de heteroglossia e sua concepção de linguagem. Também, pauta-se na compreensão das práticas linguísticas a partir do conceito de superdiversidade (VERTOVEC, 2007), o qual ajuda a explicar o atual "funcionamento das sociedades contemporâneas, marcadas pelos fluxos transnacionais, também associado aos impactos das tecnologias digitais de comunicação e informação" (ROCHA e MACIEL, 2015, p. 413). Enfatizam que as práticas linguísticas atuais caracterizam-se por usos híbridos e uma teoria fechada de linguagem já não responde à compreensão e análise dessas novas práticas. Portanto, reivindicam um novo espaço para a discussão da concepção de linguagem, 
bem como de uma pedagogia linguística voltada à justiça social. Observamos que, neste estudo, o termo translinguagem aparece como um conceito, o que difere, por exemplo, da proposta de Wei (2018) que o trata como uma "teoria prática".

O trabalho de Ferrari (2016) constitui-se de uma pesquisa de campo, realizada em um Centro de Atendimento Integral Para Criança (CAIC), localizado em uma região de fronteira entre o estado de Mato Grosso (Brasil) e Puerto Suárez (Província de Germán Busch, no Departamento de Santa Cruz - Bolívia). Toma como pressupostos, principalmente, o trabalho de García (2014); Canagarajah (2013), os quais, ao estudarem contextos linguisticamente complexos, defendem uma recontextualização do ensino de línguas, sobretudo quando se trata de situação em que está em jogo mais de uma língua (materna/s e estrangeira/s). Ferrari (2016) assim descreve parte do contexto de sua pesquisa: "É uma sala onde 95\% dos alunos tem como língua materna o espanhol, vivem em solo boliviano e estão estudando em uma escola brasileira, onde o idioma oficial é o português" (p. 6). Utiliza-se, portanto, do conceito de translinguagem para justificar as práticas linguísticas que se dão em um mundo no qual as fronteiras já não são tão fixas e estáveis, haja vista os frequentes e atuais fluxos migratórios. Em sua pesquisa a autora consegue identificar práticas de translinguagem, em que professora e alunos, para desenvolverem conhecimento, no processo interacional, se utilizam do português e do espanhol.

O trabalho de Santos (2017) investiga práticas translíngues em contexto de fronteira Brasil/Paraguai/Argentina, ao analisar a escrita de uma aluna que vive em contexto brasileiro, porém criada em contexto paraguaio. A escrita da aluna é atravessada por marcas do português, do espanhol e do guarani, em uma mescla que carrega traços específicos de cada uma das línguas que fazem parte da vivência da estudante. A pesquisadora, neste caso, salienta que:

esse amálgama tão característico de sujeitos bilíngues na fronteira recebe um tratamento estigmatizador, no sentido de que seus praticantes não sabem bem nem uma língua, nem outra, posicionamento bastante presente nas licenciaturas de professores de língua, nesse contexto. (SANTOS, 2017, p. 528)

Neste sentido, Santos (2017) considera que a prática translíngue é reconhecida como uma transgressão à norma culta das línguas, ou ainda, como erro que deve ser corrigido e erradicado. Portanto, um trabalho mais voltado à formação docente, com viés translinguístico, poderia contribuir para uma melhor compreensão do fenômeno.

O trabalho de Milozo e Gattolin (2019) constitui-se em uma pesquisa de caráter qualitativo-interpretativista, de cunho etnográfico, no qual analisam o processo de ensino/aprendizagem de português por um aluno italiano. $\mathrm{O}$ artigo 
baseia-se nos trabalhos a respeito do conceito de translinguagem desenvolvidos por Garcia et all (2017) e Canagarajah (2013).

A pesquisa foi realizada em um curso de extensão de português para estrangeiros, oferecido por uma universidade pública localizada no estado de São Paulo, Brasil, e tinha como premissa o ensino voltado à comunicação cotidiana. A professora assumiu a função de professora-pesquisadora e o curso consistiu em atividades que estimulavam a interação entre os participantes e a construção do conhecimento em língua e aspectos culturais.

$\mathrm{O}$ artigo descreve como este estudante, ao integrar seus conhecimentos de italiano e espanhol os usava para aprender português. Pelo viés metodológico da translinguagem como uma prática, as autoras analisam fragmentos de interação entre a professora e o estudante e buscam evidenciar a forma pela qual o aluno se insere em uma prática translíngue, por meio de suas reflexões metalinguísticas, quando mescla e contrasta idiomas em suas conversações cotidianas com amigos e familiares - em inglês, espanhol e italiano.

Ainda, outro elemento presente em seu trabalho, voltado à noção de translinguagem, refere-se à separação entre as línguas. As autoras analisam como aluno se esforça para tentar separá-las, quando precisa expressar-se em português. Segundo as autoras, o estudante

\footnotetext{
" alega não conseguir "separar" o português e o espanhol na sua prática oral, ainda que, na sua opinião, sua "gramática em espanhol" não seja tão boa quanto sua gramática em português, o qual deveria "tentar de aprender de verdade", isto é, estudar a língua formalmente" (MILOZO e GATTOLIN, 2019, p. 115).
}

Para o aluno, essa separação até acontece pelo fato de nomeá-las, porém, tal feito psicolinguisticamente parece não ocorrer. Neste sentido, as autoras defendem que, na comunicação com este estudante, não apenas ocorre uma troca ou mudança de língua, mas a translinguagem em movimento.

Diante dos resultados da pesquisa, as autoras propõem mudanças no ensino de línguas considerando três argumentos: a) a língua como não somente estrutura, mas como interativa e dinâmica; b) as dimensões extralinguísticas da comunicação humana e, c) no processo de ensino/aprendizagem não se aprende somente língua, mas também normas e valores.

O trabalho de Oliveira e Bulegon (2019) tem como foco principal tecer reflexões acerca do ensino de português como língua de acolhimento, com base no conceito de translinguagem. Este artigo, que analisa um contexto de ensino de Educação de Jovens e Adultos (EJA), tenta descrever as suas práticas de acordo com algumas premissas do Translanguaging, conforme descrito nos trabalhos de 
García (2009, 2014 e outros) - "conscientização linguística, a interculturalidade e o empoderamento dos alunos dentro e fora de sala de aula" (p. 430). Ainda, apontam a necessidade de reconfigurar o ensino de línguas, tendo em vista a origem de seus alunos - em sua maioria imigrantes e refugiados. Neste sentido, o ensino de línguas não pode ter uma perspectiva assimilacionista, mas considerar a cultura e intersubjetividade desses alunos, tal como argumenta García (2009) em relação ao conceito de translinguagem.

Este artigo vincula-se ao que se chama de pedagogia translíngue:

compreendemos a pedagogia translinguagem como uma forma de valorizar a língua e cultura do aluno em sala de aula, a fim de os alunos se sintam escutados e valorizados pelo menos na sala de aula e que promovam sua agentividade (BULEGON ${ }_{i}$ SOARES, 2019) dentro e fora dela. (OLIVEIRA e BULEGON, 2019 p. 437).

Defendem que a pedagogia translíngue pode devolver a voz a estes imigrantes ou refugiados, bem como empoderá-los. Essa pesquisa foi realizada com alunos haitianos, com repertórios linguísticos entre o crioulo haitiano e o francês, em um contexto de aprendizagem de português. A metodologia buscou "i) a conscientização linguística e valorização do repertório linguístico dos alunos; ii) promoção da interculturalidade na sala de aula, iii) promoção do empoderamento dos alunos (OLIVEIRA e BULEGON, 2019, p. 440).

Na descrição das aulas, consta como pressupostos a conscientização e valorização do repertório linguístico do aluno, por meio do reconhecimento de aspectos parecidos e diferentes entre as línguas; interculturalidade, por meio do reconhecimento das semelhanças e diferenças entre as culturas existentes no grupo e empoderamento, por meio da inclusão das línguas existentes no grupo e na comunidade.

Nas conclusões, as autoras não apresentam o resultado do trabalho em si, porém, partindo de alguns dos princípios da translinguagem, ressaltam que ensinar línguas hoje deve promover a conscientização linguística dos alunos; a troca intercultural e a agentividade dos alunos nas aulas "diminuindo o caráter colonizador do ensino e valorizando as subjetividades do alunado" (OLIVEIRA e BULEGON, 2019, p. 442). A pesquisa apresentada nos leva a considerar que a translinguagem serviu como uma teoria prática de linguagem para o desenvolvimento das atividades do curso.

O conjunto de trabalhos analisados mostra de que forma o conceito de translinguagem tem sido abordado em contexto estrangeiro e brasileiro. Os artigos desenvolvidos em contexto estrangeiro, notadamente publicados no Reino Unido, destacam a translinguagem tanto como um conceito quanto uma pedagogia para 
aprender e ensinar línguas. Seus debates ainda se dão em torno do desenvolvimento do bilinguismo no contexto escolar, no sentido de desenvolver duas ou mais línguas ou, ainda, revitalizar línguas minoritárias. Em contexto brasileiro, igualmente, a translinguagem é concebida tanto como um conceito quanto como uma prática, ou, em outras palavras, para citar o argumento de Wei (2018) uma "teoria prática de linguagem". Não estão em jogo o desenvolvimento de bilinguismos, práticas de tradução ou outros conceitos ligados ao uso de mais de uma língua no contexto escolar. A translinguagem está mais voltada para o reconhecimento das línguas dos falantes, de sua cultura e, portanto, atua como forma de dar a voz à alunos estrangeiros, imigrantes ou refugiados, ou ainda, de promover espaços para diferentes usos linguísticos em locais marcados pelo plurilinguismo.

\section{CONSIDERAÇÕES FINAIS}

Tendo em vista os estudos analisados neste artigo, o ensino pautado em uma pedagogia translíngue, em muito contribuiria para uma aprendizagem mais inclusiva e com mais possibilidades de acesso pleno ao conhecimento. Neste sentido, destacamos o conceito de translinguagem, como uma teoria prática de linguagem, a qual poderia fazer parte do desenvolvimento de novas estratégias de ensino e de formação docente direcionadas ao trabalho em cenários multilíngues.

Nos contextos onde já realizamos pesquisas, assim como em outras comunidades de imigrantes/fronteira, especialmente nas do estado do Paraná, o uso das línguas vem marcado pelo preconceito ou por sua ridicularização, tal como relatado por Wei (2018) na situação do "Chinglish". Há menções corriqueiras acerca do falante com traços "rurais", no caso de ser de região de imigração, ou ainda, a do "portunhol" ou "português mal falado", no caso de ser habitante de uma região de fronteira.

Em vista disso, ressaltamos a necessidade de propostas, tanto de teorias quanto de práticas, que visem a ressignificar os usos das línguas. O conceito de translinguagem nos lembra que a relação entre as línguas é hierarquizada, sobretudo em contextos em que há a coexistência de mais de uma língua. Neste sentido, defendemos que é pela língua que se dá o acesso ao conhecimento e também o desenvolvimento da identidade do falante e de sua inserção social.

Assim, em relação à translinguagem e aos estudos analisados, algumas perguntas merecem ser respondidas, entre elas, podemos incluir: i) como o conceito tem sido abordado nas diferentes pesquisas? ii) em um contexto multilíngue, as práticas ainda são direcionadas pelo viés do monolinguismo? iii) que mudanças 
podem ser implementadas, tanto na formação de professores quanto nas práticas pedagógicas, a partir do estudo da translinguagem?

Em relação à primeira questão, foi possível observar que a translinguagem tem sua base, sobretudo, nos estudos García (2009 e outros), entre outros pesquisadores, tais como Canagarajah (2011 e 2013); Creese \& Blackladge (2014), os quais defendem uma pedagogia voltada ao plurilinguismo no ambiente escolar e acadêmico. Os textos analisados, portanto, baseiam-se nesse conjunto de autores e se pautam na translinguagem tanto como teoria quanto como prática, embora algumas críticas estejam sendo feitas ao conceito, conforme abordado na primeira parte deste trabalho.

Em relação ao segundo questionamento, o qual versa acerca do uso das línguas em um ambiente multilíngue, observamos que há a predominância, nos contextos retratados nos estudos, para a existência de níveis hierárquicos entre as línguas, pois, muito embora estejam em situações multilíngues, certas línguas servem a determinados papeis, seja como meio de instrução ou de interação. No entanto, também foi possível observar, sobretudo nos trabalhos que trazem a análise de depoimentos de falantes que, em muitas situações, as línguas são percebidas funcionando em conjunto, o que caracterizaria uma situação de translinguagem.

Para finalizar, em relação às mudanças que podem ser implementadas nas práticas pedagógicas, destacamos a necessidade de oportunizar espaços de formação docente, inicial e continuada, pelo viés da translinguagem. Neste sentido, ao se trabalharem e ao se propiciarem experiências educativas a partir desse conceito - que funciona como teoria e prática - poderia haver avanços significativos em relação ao ensino de línguas, ao serem facilitados processos interativos em sala de aula, por meio do reconhecimento da diversidade linguística, da intersubjetividade dos falantes e do próprio processo de ensinar. Isso posto, reiteramos a necessidade de um aprofundamento em relação aos estudos na área da translinguagem, bem como estabelecer sua relação com a área das práticas e das políticas linguísticas.

\section{REFERÊNCIAS}

BLACKLEDGE, A. and A. CREESE (2014). Heteroglossia as Practice and Pedagogy. In: A Blackledge and A Creese (eds). Heteroglossia as Practice and Pedagogy. New York: Springer, 1-20.

BLOMMAERTJ \& RAMPTON, B. (2011). Language and superdiversity. Diversities, 13 (2),1-22. 
BLOMMAERT J. (2014). From mobility to complexity in sociolinguistic theory and method. Tilburg Papers in Culture Studies, 103. Tilburg, The Netherlands: Tilburg University.

CANAGARAJAH, S. (2011). Translanguaging in the classroom: Emerging issues for research and pedagogy. Applied Linguistics Review, 2,1-28.

CANAGARAJAH, S. (2013). Translingual practice: Global Englishes and cosmopolitan relations. Abingdon, UK: Routledge.

CENOZ, J. (2017). Translanguaging in School Contexts: International Perspectives, Journal of Language, Identity \& Education, 16:4, 193 -198. DOI: 10.1080/15348458.2017.1327816.

COOK, V.J. (2001). Using the first language in the classroom. Canadian Modern Language Review, 57,. 402-423.

CONTEH, J. (2018). Translanguaging. ELT Journal, Volume 72, Issue 4, Pages 445-447, https://doi.org/10.1093/elt/ccy034.

COPLAND F., CREESE, A (with Frances Rock and Sara Shaw). (2015). Linguistic Ethnography: Collecting, Analyzing, and Presenting Data. London: Sage Publications.

COSTE, D., MOORE, D., ZARATE, G. (1997). Compétence plurilingue et pluriculturelle, Strasbourg : Conseil de l'Europe. Publié aussi dans Le français dans le monde. Recherches et applications.

CREESE A., \& BLACKLEDGE A. (2010). Translanguaging in the bilingual classroom: A pedagogy for learning and teaching. Modern Language Journal, 94,103-115.

CREESE, A., \& BLACKLEDGE, A. (2015). Translanguaging and identity in educational settings. Annual Review of Applied Linguistics, 35:20-35,

DENZIN, N. K. e LINCOLN, Y. S. (Orgs.). (2006). O planejamento da pesquisa qualitativa: teorias e abordagens. 2. ed. Porto Alegre: Artmed.

DUARTE, J. (2019). Translanguaging in mainstream education: a sociocultural approach. International Journal of Bilingual Education and Bilingualism, 22:2, 150-164. DOI: $10.1080 / 13670050.2016 .1231774$.

FERRARI, L. (2016). As práticas translíngues emergentes nas aulas de escola da fronteira Brasil-Bolívia: negociação de sentidos e justiça social. In.: VI Seminário Internacional AMÉRICA PLATINA (VI SIAP) e I Colóquio UNBRAL de Estudos Fronteiriços: América Platina: alargando passagens e desvendando os labirintos da integração". Campo Grande. UEMS. 
FONSECA, A. A.; WEISS, D. B e DUTRA, M. C. DE P. (2018). Memória fonológica de falantes de português brasileiro como língua de herança.Domínios de Lingu@gem. Uberlândia. vol. 12, n. 2 . abr. - jun., p. 1267-1293. DOI: 10.14393/DL34-v12n2a2018-22.

GARCÍA, O. (2009). Bilingual Education in the 21st Century: A Global Perspective. Wiley.

GARCÍA, O., \& KLEIFGEN, J. (2010). Educating emergent bilinguals: Policies, programs, and practices for English Language Learners. New York, NY: Teachers College Press.

GARCÍA, O, WEI, L. (2014). Translanguaging: Language, Bilingualism and Education. Basingstoke, Hampshire: Palgrave Macmillian.

GARCÍA, O. (2018). Translanguaging, pedagogy and creativity. In: Erfurt, J., Carporal, E. \& Weirich, A. (eds.). Éducation plurilingue et pratiques langagières: Hommage à Christine Hélot. Berlin: Peter Lang., pp.39-56.

GARCÍA, O. (2019). The Curvas of translanguaging. In: Zhongfeng, T. and Link H. (Eds.). Positive synergies. Translanguaging and critical theories in education. New York: John Benjamins. Translation and Translanguaging in Multilingual Contexts. 5(1), 86-93.

GARCÍA, O. \& OTHEGUY, R. (2019). Plurilingualism and translanguaging: Commonalities and divergences. International Journal of Bilingual Education and Bilingualism. DOI: 10.1080/13670050.2019.1598932.

HELLER, M. (1999). Linguistic Minorities and Modernity: A Sociolinguistic Ethnography. London: Longman.

HORNBERGER, N. H. (2002). Multilingual language policies and the continua of biliteracy: An ecological approach. Language Policy, 1, 27-51.

JASPERS, J. (2017). The transformative limits of translanguaging. Language \& Communication, 58. December, 2017. DOI: 10.1016/j.langcom. 2017.12.001.

JONES, B. (2010). Amrywiaeth caleidosgopig: Addysg ddwyieithog yng Nghymru heddiw [Kaleidoscopic variety: Bilingual education in Wales today]. Retrieved from http:// www.gwerddon.org/5_amrywiaeth_caleidosgopig-85.aspx.

JONES, B., \& LEWIS, G. (2014). Language arrangements within bilingual education. In: E. M. Thomas \& I. Mennen (Eds.), Advances in the study of bilingualism, Bristol, UK: Multilingual Matters. pp. 143-172. 
JONES, B. (2017). Translanguaging in Bilingual Schools in Wales. Journal of Language, Identity \& Education, 16:4, 199-215. DOI: 10.1080/15348458.2017.1328282.

JONSSON, C. (2019). 'What is it called in Spanish?’: Parallel Monolingualisms and translingual classroomtalk. ClassroomDiscourse, 10:3-4,323-346,DOI: 10.1080/19463014.2019.1631197.

JØRGENSEN, J. N. (2008). Polylingual Languaging around and among Children and Adolescents. International Journal of Multilingualism 5 (3): 161-176. doi: $10.1080 / 14790710802387562$.

KRAUSE-LEMKE, C. (2010). Políticas e práticas linguísticas: um estudo sobre o ensino de língua espanhola em um contexto multilíngue no Paraná - Brasil. Tese (Doutorado em Educação) - Faculdade de Educação, Universidade de São Paulo, São Paulo, 2010. doi:10.11606/T.48.2010.tde-16122010-152622.

LEWIS, G. JONES, B. \& BAKER, C. (2012). Translanguaging: developing its conceptualisation and contextualisation. Educational Research and Evaluation, 18:7, 655670. DOI: 10.1080/13803611.2012.718490.

MILOZO, G. GATTOLIN. B. (2019). "Eles començam sanguear": translinguagem como prática criativa e de construção de conhecimento em Português Língua Estrangeira. Pensares em Revista, São Gonçalo-RJ, n. 15, p. 109-125. DOI: 10.12957/pr.2019.41987.

OLIVEIRA, B. S. de; BULEGON, M. (2019). Reflexões sobre o ensino de português como língua de acolhimento pelo viés da pedagogia translanguaging. Revista EntreLínguas, Araraquara, v. 5, n. 2, p. 430-445, jul./dez. DOI: 10.29051/el.v5i2.12958.

PAVLENKO, A. (2017). "Superdiversity and why it isn't". In: Sloganizations in Language Education Discourse, edited by S. Breidbach, L. Kuster and B. Schmenk (in press). Bristol: Multilingual Matters.

ROCHA, C. H.; MACIEL, R. F. (2015). Ensino de língua estrangeira como prática translíngue: articulações com teorizações bakhtinianas. Revista DELTA,31-2, p. 411 -445. < http:// dx.doi.org/10.1590/0102-4450437081883001191>.

SANTOS, M. E. P. (2017). "Portunhol Selvagem": translinguagens em cenário translíngue/ transcultural de fronteira. Gragoatá, Niterói, v.22, n. 42, p. 523-539, jan.-abr. 2017. $<$ http://dx.doi.org/10.22409/gragoata.2017n42a890>.

SMITH, H., ROBERTSON, L. AUGER, N., AZAOUI, B., DERVIN, D., GAL, N., LAYNE, H. e L. WYSOCKI: (2017). A Pedagogy for bi/plurilingual pupils: Translanguaging. University of Newcastle. 
VERTOVEC, S. (2007). Super-diversity and its implications. Ethic and Racial Studies, 30/6, p. 1024-1054.

WEI, L. (2011). Moment analysis and translanguaging space: Discursive construction of identities by multilingual Chinese youth in Britain. Journal of Pragmatics, 43, pp. 1222 1235.

WEI, L. (2018). Translanguaging as a Practical Theory of Language. Applied Linguistics. 39/1: 9-30, Doi:10.1093/applin/amx039.

WILLIAMS, C. (1994). Arfarniad o Ddulliau Dysgu ac Addysgu yng Nghyd-destun Addysg Uwchradd Ddwyieithog, [An evaluation of teaching and learning methods in the context of bilingual secondary education]. Unpublished doctoral thesis, University of Wales, Bangor.

Recebido: 10/4/2020

Aceito: 29/10/2020

Publicado: 3/11/2020 